\title{
Penigkatan Aktivitas Dan Hasil Belajar Ekonomi Kelas XI IPS 1 Melalui Penerapan Metode Snowball Throwing SMA Negeri 1 Paguat Tahun Pelajaran 2019/2020
}

\author{
Achmad Polotoy \\ Sma Negeri 1 Paguat \\ achmadpolotoy2@gmail.com
}

Received: 13 August 2021; Revised: 02 October 2021; Accepted: 14 December 2021

DOI: http://dx.doi.org/10.37905/aksara.8.1.349-362.2022

\begin{abstract}
Abstrak
Penelitian ini bertujuan untuk meningkatkan aktivitas dan hasil belajar ekonomi kelas XI IPS 1 melalui penerapan metode pembelajaran Snowball pada mata pelajaran ekonomi di SMA Negeri 1 Paguat Tahun Ajaran 2019/2020. Melalui metode Snowball Throwing ini diharapkan siswa mampu mencapai tujuan peningkatan aktivitas dan hasil belajar ekonomi. Penelitian ini merupakan Penelitian Tindakan Kelas yang dilakukan dalam dua tahapan siklus. Siklus I terdiri dari dua kali pertemuan dan siklus II terdiri dari satu kali pertemuan. Setiap siklus terdiri dari empat tahap yaitu perencanaan, pelaksanaan tindakan, pengamatan dan refleksi. Subjek dalam penelitian ini adalah siswa kelas XI IPS 1 SMA Negeri 1 Paguat yang berjumlah 22. Indikator keberhasilan pada penelitian ini adalah apabila $75 \%$ siswa aktif terlibat dalam pembelajaran dan juga terjadi peningkatan hasil belajar pada tiap sikluus melalui posttest dan apabila $75 \%$ siswa dapat mencapai nilai KKM. Hasil penelitian menunjukkan bahwa dengan penerapan metode snowball throwing di kelas XI IPS 1 skor aktivitas belajar siswa pada masing-masing indikator secara keseluruhan meningkat $19,17 \%$, dari rata-rata siklus I sebesar $60 \%$ menjadi $79,17 \%$ pada siklus II. Peningkatan ketuntasan hasil belajar siswa meningkat dari siklus I sebanyak 11 siswa menjadi 16 siswa yang mencapai nilai KKM pada siklus II.
\end{abstract}

Kata Kunci: Metode Pembelajaran Snowball Throwing, Aktivitas Belajar Ekonomi, Hasil Belajar Ekonomi

\section{PENDAHULUAN}

Proses belajar di kelas mengharuskan aktivitas untuk mampu belajar aktif dan mandiri melalui kegiatan mengamati, menanya, mengumpulkan informasi, mengolah informasi, mengkomunikasi dan mencipta yang sudah tertuang dalam Rencana Pelaksanaan Pengajaran (RPP) yang telah disusun oleh guru. Proses belajar siswa untuk mendapatkan pengetahuan disebut dengan aktivitas belajar. Siswa dituntut aktif mencari informasi maupun materi pelajaran dan peran guru hanya sebagai fasilitator dalam siswa beraktivitas di kelas serta membuat kesimpulan yang benar dari penyampaian materi yang dikemukanan oleh siswa.

Proses belajar yang seperti inilah yang diharapkan mampu meningkatkan kualitas pendidikan di Indonesia. Namun masalah yang sering terjadi terkait dengan pelaksanaan proses pembelajaran sesuai dengan kurikulum 2013 yaitu adanya ketidaksesuaian penerapan praktik dengan tujuan pembelajaran kurikulum 2013 itu sendiri, di mana peranan siswa dalam pembelajaran yang belum maksimal, justru guru masih mendominasi proses belajar mengajar dibandingkan dengan siswanya.

Ada berbagai macam metode pembelajaran kooperatif, salah satu metode pembelajaran yang dimungkinkan dapat meningkatkan hasil belajar siswa adalah metode Snowball Throwing. Metode pembelajaran Snowball Throwing memiliki kelebihan sendiri dibandingkan dengan metode pembelajaran yang lain, merupakan paradigma pembelajaran efektif yang merupakan rekomendasi UNESCO, yakni: 
belajar mengetahui (learning to know), belajar bekerja (learning to do), belajar hidup bersama (learning to live together), dan belajar menjadi diri sendiri (lerning to be). Penggunaan metode pembelajaran Snowball Throwing dapat melibatkan siswa menjadi aktif. Melalui penerapan metode snowball throwing, dapat melatih siswa berani mengemukakan pendapat, bekerja sama dan tanggung jawab, suasana pembelajaran menjadi lebih menyenangkan karena siswa seperti bermain dengan melempar bola kertas kepada kelompok lain.

Penggunaan metode pembelajaran snowball throwing melibatkan siswa untuk membuat pertanyaan yang akan dilemparkan kepada kelompok lain untuk menjawab pertanyaan tersebut dan pembelajaran menjadi lebih menarik.

Berdasarkan latar belakang diatas maka dilakukan penelitian dengan judul "Peningkatan Aktivitas dan Hasil Belajar Kelas XI IPS melalui Penerapan Metode Snowball Throwing di SMA Negeri 1 Paguat Tahun Pelajaran 2019/2020".

Adapun tujuan penelitian tindakan kelas ini adalah 1. Untuk meningkatkan aktivitas belajar siswa mata pelajaran ekonomi kelas XI IPS di SMA Negeri 1 Paguat Tahun Pelajaran 2019/2020 melalui penerapan metode snowball throwing. 2. Untuk meningkatkan hasil belajar siswa mata pelajaran ekonomi kelas XI IPS di SMA Negeri 1 Paguat Tahun Pelajaran 2019/2020 melalui penerapan metode snowball throwing.

\section{KAJIAN TEORITIS}

Aktivitas belajar adalah semua kegiatan yang dilakukan oleh seseorang untuk mendapatkan pengetahuan/kemampuan baru yang dapat membawa perubahan baik perubahan pengetahuan, sikap, maupun keterampilan.

Jenis aktivitas belajar cukup komleks dan bervariasi yang melibatkan aktivitas fisik dan aktivitas mental. Dalam penelitian ini aktivitas belajar yang digunakan adalah jenis aktivitas belajar menurut Paul B. Diedrich yang meliputi aktivitas visual, aktivitas lisan, aktivitas mendengarkan, aktivitas menulis, aktivitas mental, dan aktivitas emosional.

Belajar adalah suatu proses yang menimbulkan terjadinya suatu perubahan atau pembaharuan dalam tingkah laku, berhasil atau tidaknya belajar dipengaruhi beberapa faktor. Ngalim Purwanto (2014: 102) menggolongkan faktor yang mempengaruhi belajar menjadi 2 macam, yaitu:

1) Faktor yang ada dalam diri organisme itu sendiri yang kita sebut faktor individual yang meliputi faktor kematangan, kecerdasan, latihan, motivasi, dan faktor pribadi.

2) Faktor yang ada di luar individu yang kita sebut faktor sosial. Yang termasuk faktor ini antara lain faktor keluarga, guru dan cara mengajarnya, alat-alat yang digunakan dalam belajar mengajar, lingkngan dan kesempatan yang tersedia dalam motivasi sosial.

Hasil belajar adalah tahapan puncak pencapaian tujuan pembelajaran yang meliputi aspek kognitif, afektif dan psikomotorik oleh siswa setelah melakukan kegiatan belajar. Hasil belajar ekonomi yang diteliti dalam penelitian ini berupa aspek kognitif saja, karena aspek kognitif akan dapat diketahui seberapa besar kemampuan siswa dalam menguasai isi mata pelajaran.

Hasil belajar dapat dikatakan tuntas apabila telah memenuhi kriteria ketuntasan minimum yang ditetapkan oleh pengajar mata pelajaran. Pada dasarnya untuk mengukur keberhasilan siswa dalam pembelajaran sangatlah sulit, karena nilai yang 
muncul dari hasil ulangan atau tes masih belum bisa dipastikan apakah hasil yang didapat siswa adalah hasil yang sebenarnya.

Metode Snowball Throwing merupakan salah satu model pembelajaran kooperatif. Metode pembelajaran tersebut mengandung unsur-unsur pembelajaran kooperatif. Snowball artinya bola salju sedangkan Throwing artinya melempar. Arahman (2010: 3) menyebutkan Snowball Throwing dapat diartikan sebagai suatu metode pembelajaran yang diawali dengan pembentukan kelompok yang diwakili ketua kelompok untuk mendapat tugas dari guru kemudian masing-masing siswa membuat pertanyaan yang dibentuk seperti bola (kertas pertanyaan) lalu dilempar ke siswa lain yang masing-masing siswa menjawab pertanyaan dari bola yang diperoleh. Meskipun tidak ada teori yang secara rinci mengenai metode snowball throwing, metode ini memiliki kesamaan dengan metode yang dikembangkan Malvin L. Silberman yaitu metode Collage Ball (Permainan Bola Guling) sebagai cabang dari pembelajaran Active Learning. Pembelajaran dengan metode ini menekankan peran aktif siswa dalam membangun pemahaman terhadap suatu materi. Perbedaan metode Collage Ball dengan Snowball Throwing hanya pada pengelompokan siswa. Collage Ball lebih menilai tiap-tiap individu saja tanpa adanya pembagian kelompok, sedangkan Snowball Throwing menilai aktivitas berdasarkan keaktifan masing-masing siswa dalam kelompoknya.

Pembelajaran ini sangat cocok digunakan di kelas yang siswanya kurang aktif dan hasil belajar rendah, karena metode ini menuntut siswa dalam kelompok harus berpartisipasi aktif membuat pertanyaan maupun berdiskusi merumuskan pertanyaan, otomatis ketika mereka aktif di kelas materi yang dipelajari/yang dijelaskan oleh temannya lebih gampang terserap. Dampaknya ketika guru memberikan soal latihan pada akhir pembelajaran, siswa akan mudah menjawab soal tersebut dengan baik dan benar.

\section{METODE PENELITIAN}

Jenis penelitian yang digunakan adalah jenis penelitian tindakan kelas. Penelitian tindakan kelas (PTK) adalah praktis di dalam kelas untuk memperbaiki kualitas proses pembelajaran, meningkatkan hasil belajar, dan menemukan model pembelajaran inovatif untuk memecahkan masalah yang dialami oleh pendiddik dan peserta didik.

Prosedur penelitian ini terdiri dari tahap perencanaan (planning), tahap tindakan/pelaksanaan (action), tahap pengamatan (observation), dan tahap refleksi. Teknik pengumpulan data yang digunakan dalam penelitian tindakan kelas ini yaitu 1 . Mengadakan Observasi, 2. Melaksanakan Tes dan 3. Dokumentasi.

Teknik analisis data yang digunakan pada penelitian ini diantaranya adalah sebagai berikut:

Adapun untuk mengetahui persentase keaktifan siswa :

$\%=($ Jumlah skor yang diperoleh siswa / skor maksimal $) \times 100 \%$

Untuk mengetahui skor rata-rata kelas setiap siklus menggunakan rumus sebagai berikut:

Skor rata-rata $=($ Skor seluruh siswa $/$ jumlah siswa $)$ 
Ketuntasan klasikal dapat dikatakan telah tercapai apabila nilai siswa memenuhi KKM dengan target pencapaian ideal lebih atau sama dengan $75 \%$ dari jumlah seluruh siswa dalam kelas. Untuk mengetahui ketuntasan secara klasikal dapat menggunakan rumus sebagai berikut:

$\% \mathrm{KKM}=($ Jumlah siswa yang tuntas $/$ jumlah siswa $) \times 100 \%$

\section{HASIL DAN PEMBAHASAN}

\section{Hasil Penelitian Siklus 1 Perencanaan Siklus 1}

Pelaksanaan pembelajaran pada siklus I menerapkan metode pembelajaran snowball throwing (melempar bola berisi pertanyaan). Dengan menggunakan metode ini pembelajaran di dalam kelas lebih menyenangkan karena pembelajaran yang biasa dilakukan di kelas hanya menggunakan metode ceramah. Materi tentang sistem upah dipilih sebagai tolak ukur pembelajaran yang disampaikan sebelumnya.

Peneliti juga berkoordinasi mengenai langkah-langkah pembelajaran menggunakan metode snowball throwing, post-test, dan pembagian kelompok dalam pembelajaran. Peneliti menyiapkan lembar observasi yang akan digunakan dalam penilaian Aktivitas Belajar.

\section{Pelaksanaan Siklus 1}

Peneliti meminta masing-masing kelompok memilih salah satu pertanyaan yang dibuat anggotanya untuk digulung dan dimasukkan kedalam cock. Dalam beberapa hitungan, cock dilemparkan ke kelompok lain. Setelah itu masing-masing kelompok berdiskusi dengan anggotanya dan mengerjakan soal yang ada di dalam cock tanpa melihat hand out. Selanjutnya peneliti meminta masing-masing perwakilan kelompok untuk maju menjelaskan jawaban kelompoknya di depan kelas, peneliti mengoreksi apakah jawaban-jawaban dari siswa sudah benar. Peneliti menyimpulkan hasil pembelajaran dan menginformasikan pembelajaran minggu depan masih dengan metode snowball throwing dengan materi yang masih sama, karena dalam pertemuan pertama ini masih banyak siswa yang kurang memahami bagaimana langkah-langkah penerapan pembelajaran dengan metode snowball throwing yang baik.

Pada pertemuan kedua materi yang diajarkan masih mengenai pengertian sistem upah, jenis-jenis sistem upah, faktor-faktor yang mempengaruhi upah, dan syarat-syarat upah. Tujuan pembelajaran yang ingin dicapai adalah siswa mampu menguasai materi sistem upah dengan pembelajaran menggunakan metode snowball throwing dan dapat menjelaskan materi tersebut dengan baik. Pembelajaran diawali dengan menginformasikan materi yang akan disampaikan kepada siswa sekaligus menjelaskan metode yang akan digunakan dalam pembelajaran. Peneliti mengelompokkan siswa ke dalam kelompok secara acak dengan cara berhitung urut 1 sampai dengan 5. Karena jumlah siswa yang hadir ada 19 orang, maka ada 5 kelompok dengan masing-masing anggota 4 siswa dan 1 kelompok beranggotakan 3 siswa, nama kelompok berdasarkan jenis warna yang meliputi merah, kuning, hijau, biru, dan orange. Masing-masing siswa pada setiap kelompok diberikan name tag untuk dituliskan nama. Setelah kelompok terbentuk, selanjutnya masing-masing kelompok dibagikan 1 bendel hand out yang berisi materi tentang sistem upah, juga name tag, kertas sesuai warna untuk menuliskan soal dan cock. 
Peneliti meminta masing-masing ketua kelompok untuk maju ke depan menerima materi yang akan dibuat oleh masing-masing kelompok dan menjelaskan materi kepada anggotanya. Setelah itu masing-masing siswa diminta membuat satu pertanyaan mengenai materi yang sudah dijelaskan. Peneliti meminta masing-masing kelompok memilih salah satu pertanyaan yang dibuat anggotanya untuk digulung dan dimasukkan kedalam cock. Dalam beberapa hitungan, cock dilemparkan ke kelompok lain. Setelah itu masing-masing kelompok berdiskusi dengan anggotanya dan mengerjakan soal yang ada di dalam cock tanpa melihat hand out. Selanjutnya peneliti meminta masing-masing perwakilan kelompok untuk maju menjelaskan jawaban kelompoknya di depan kelas, peneliti mengoreksi apakah jawaban-jawaban dari siswa sudah benar. Dan memberikan reward kepada 3 kelompok yang paling aktif dan mampu menjawab pertanyaan-pertayaan dengan baik dan benar.

\section{Pengamatan Siklus 1}

\section{1) Aktivitas Belajar}

\begin{tabular}{|c|c|c|c|}
\hline Indikater Aktivitas Belajar & Kasegori & Persentase & Jumlalis Siswa \\
\hline \multirow{3}{*}{ Membaca materi pelajaran } & Tidak aktif & $0 \%$ & $\mathbf{a}$ \\
\hline & Cukup aktif & $26,32 \%$ & 5 \\
\hline & Aktif & $73,68 \% 5$ & 14 \\
\hline \multirow{3}{*}{$\begin{array}{l}\text { Membuat pertanyaan } \\
\text { menjawab pertanyaan dari } \\
\text { guru atau teman }\end{array}$} & Tidak aktif & ass & $\mathbf{a}$ \\
\hline & Cukcup aktif & $47,37 \%$ & 9 \\
\hline & Aktif & $52,6.3 \%$ & 10 \\
\hline \multirow{3}{*}{$\begin{array}{l}\text { Mendengarkan penjelasan } \\
\text { guru gaat pembelajaran }\end{array}$} & Tidak aktif & $11 \%$ & 3 \\
\hline & Cukup akctif & 47,3756 & 9 \\
\hline & Aktif & $42,11 \%$ & 3 \\
\hline \multirow{3}{*}{$\begin{array}{l}\text { Mencatat materi pelajaran } \\
\text { yang telah disampaikan } \\
\text { guru. }\end{array}$} & Tidak aktif & $11 \%$ & 3 \\
\hline & Cukcup aktif & $42,11 \%$ & 3 \\
\hline & Aktif & $47,37 \%$ & 9 \\
\hline \multirow{3}{*}{$\begin{array}{l}\text { Bekerja sama dengan } \\
\text { teman sekelompok }\end{array}$} & Tidak aktif & ass & o \\
\hline & Cukup aktif & $36,84 \%$ & 3 \\
\hline & Aktif & $63,16 \% 5$ & 12 \\
\hline \multirow{3}{*}{$\begin{array}{l}\text { Antuaias dalam mengilati } \\
\text { pembelajaran dengan } \\
\text { menggunakan metode } \\
\text { snowball tivrowing }\end{array}$} & Tidak aktir & ass & $\mathbf{a}$ \\
\hline & Cukup aktif & $21,05 \%$ & 4 \\
\hline & Aktif & $39 \%$ & 15 \\
\hline $\begin{array}{l}\text { Rata - rata indikator } \\
\text { aktivitas }\end{array}$ & Siswa Aktif & $60 \%$ & 11,4 \\
\hline
\end{tabular}

Berdasarkan data diatas dapat diketahui dari indikator aktivitas, indikator siswa yang aktif membaca materi pelajaran 73,68 \% atau 14 dari 19 siswa aktif, bertanya kepada peneliti/guru atau teman saat pembelajaran berlangsung 52,63\% atau 10 dari 19 siswa aktif, mendengarkan penjelasan peneliti/guru 42,11\% atau 7 dari 19 siswa aktif, mencatat materi pelajaran yang telah dijelaskan oleh guru 47,37\% atau 9 dari 19 siswa aktif, berdiskusi dengan sesama anggota kelompoknya 63,16\% atau 12 siswa 
aktif dan antusias dalam mengikuti pembelajaran yang berlangsung menggunakan metode snowball throwing 79\% atau 15 dari 19 siswa aktif mengikuti kegiatan pembelajaran dengan menggunakan metode snowball throwing. Hal ini memberikan kesimpulan bahwa Aktivitas Belajar siswa di dalam siklus I masih rendah dan belum mencapai indikator keberhasilan.

Dari data di atas diketahui bahwa masih ada 5 indikator aktivitas belajar pada siklus I belum mencapai kriteria minimal yaitu 75\%. Secara keseluruhan, persentase rata aktivitas belajar ekonomi pada siklus I sebesar $60 \%$ masih berada di bawah kriteria keberhasilan tindakan yaitu sebesar $75 \%$ sehingga belum dikatakan berhasil.

2) Hasil Belajar

Hasil Belajar Ekonomi pada siklus I diperoleh dari soal post test yang dilakukan pada akhir pelaksanaan tindakan.

Tabel 2. Hasil Posttest Siklus 1

\begin{tabular}{|c|l|c|}
\hline No & \multicolumn{1}{|c|}{ Keterangan } & Post Test \\
\hline 1 & Nilai Tertinggi & 100 \\
\hline 2 & Nilai Terendah & 60 \\
\hline & Rata - Rata Nilai & 80 \\
\hline
\end{tabular}

Tabel 3. Siswa yang sudah dan belum mencapai KKM Siklus 1

\begin{tabular}{|c|c|c|c|c|}
\hline \multirow{2}{*}{ Keterangan } & \multicolumn{2}{|c|}{ Jumlah siswa } & \multicolumn{2}{c|}{ Persentase } \\
\cline { 2 - 5 } & $<75$ & $>75$ & $<75$ & $>75$ \\
\hline Post Test & 5 & 14 & $26 \%$ & $74 \%$ \\
\hline
\end{tabular}

Berdasarkan data pada kedua tabel di atas dapat dilihat bahwa rata-rata nilai post test adalah 80 pada siklus I, akan tetapi nilai post test siswa yang mencapai KKM adalah 74\%. Dari data di atas, hasil siklus I ini belum menunjukkan keberhasilan tindakan, karena dari aktivitas belajar dan hasil belajar sendiri belum mencapai $75 \%$ tingkat aktivitas maupun persentase ketuntasan hasil belajar siswa. oleh karena itu perlu di adakan siklus II.

\section{Refleksi Siklus 1}

Dari kegiatan refeksi dapat diketahui permasalahan atau kendala yang dihadapi serta kelebihan dari model pembelajaran snowball throwing. Kendala yang ada di dalam siklus I diantaranya yaitu sebagai berikut:

1) Awalnya peneliti masih membutuhkan penyesuaian dan sedikit kesulitan dalam mengkondisikan siswa pada saat model pembelajaran snowball throwing berlangsung, karena belum pernah menerapkan sebelumnya.

2) Siswa masih kesulitan dalam menerapkan langkah-langkah pembelajaran dengan menggunakan metode snowball throwing ini.

3) Alokasi waktu diskusi yang direncanakan kurang tepat, karena siswa masih berkutat dengan soal yang diberikan saat pembelajaran berlangsung. Adanya kendala seperti ini, peneliti/guru perlu mengkondisikan siswa agar waktu yang telah dialokasikan dapat digunakan dengan efisien.

4) Hasil post test siklus I menunjukkan 14 siswa atau $74 \%$ siswa sudah mencapai KKM yang ditetapkan sekolah yaitu 75. Akan tetapi ketuntasan masih belum dapat 
mencapai kriteria keberhasilan pembelajaran yaitu minimal $75 \%$ siswa di dalam kelas dapat mencapai KKM.

Selain adanya kendala yang dihadapi pada siklus I, penerapan model pembelajaran snowball throwing juga memiliki kelebihan, diantaranya yaitu:

1) Model pembelajaran snowball throwing memberikan kebebasan siswa dalam memahami materi pelajaran baik dengan mencari tahu pada sumber belajar, berdiskusi dengan teman dan juga bertanya kepada guru.

2) Dalam pembelajaran diskusi memang sangat penting, yaitu melatih siswa untuk bekerja sama dalam memecahkan masalah atau saling membantu memberikan pemahaman sehingga bisa diselesaikan dengan baik.

3) Soal yang diberikan antar kelompok membantu siswa untuk banyak berlatih. Latihan tersebut diharapkan dapat meningkatkan pemahaman terhadap materi yang dipelajari.

\section{Hasil Penelitian Siklus II}

\section{Perencanaan Siklus II}

Berdasarkan data yang diperoleh dari siklus I diketahui bahwa aktivitas dan hasil belajar siswa belum optimal, meskipun dari segi hasil belajar tingkat ketuntasan meningkat 46,73\% dibandingkan dengan hasil ulangan harian. Oleh karena itu perlu dilakukan kembali pembelajaran ekonomi dengan metode snowball throwing siklus II. Perencaaan siklus II sendiri tidak jauh berbeda dengan siklus I, disiapkan pula berbagai perlengkapan yaitu Rencana Pelaksanaan Pembelajaran (RPP), Hand out lembar observasi, dan soal posttest.

Pelaksanaan Siklus II

Peneliti juga menginformasikan materi yang akan disampaikan kepada siswa hari itu mengenai pengertian pengangguran, jenis-jenis pengangguran, dan cara mengatasi pengangguran.

Peneliti langsung mengelompokkan siswa ke dalam kelompok secara acak seperti siklus I dengan cara berhitung urut 1 sampai dengan 5. Karena jumlah siswa yang hadir ada 20 orang, maka ada 5 kelompok dengan masing-masing anggota kelompok terdiri dari 4 siswa. Nama kelompok berdasarkan jenis warna yang meliputi merah, kuning, hijau, biru, dan orange. Masing-masing siswa pada setiap kelompok diberikan name tag untuk dituliskan nama. Setelah kelompok terbentuk, selanjutnya masing-masing kelompok dibagikan 1 bendel hand out yang berisi materi tentang pengangguran, juga name tag, kertas sesuai warna untuk menuliskan soal dan cock.

Peneliti meminta masing-masing ketua kelompok untuk maju ke depan menerima materi yang akan dibuat oleh masing-masing kelompok dan menjelaskan materi kepada anggotanya. Setelah itu masing-masing siswa diminta membuat satu pertanyaan mengenai materi yang sudah dijelaskan. Peneliti meminta masing-masing kelompok memilih salah satu pertanyaan yang dibuat anggotanya untuk digulung dan dimasukkan kedalam cock. Setelah itu masing-masing kelompok berdiskusi dengan anggotanya dan mengerjakan soal yang ada di dalam cock tanpa melihat hand out. Selanjutnya peneliti meminta masing-masing perwakilan kelompok untuk maju menjelaskan jawaban kelompoknya di depan kelas, peneliti mengoreksi apakah jawaban-jawaban dari siswa sudah benar. Peneliti memberikan reward kepada 3 kelompok yang paling aktif dan mampu menjawab pertanyaan-pertayaan dengan baik 
dan benar. Pada siklus II ini semua kelompok sudah mampu menjawab pertanyaan yang diberikan kelompok lain dengan benar. Setelah selesai membagikan reward kepada 3 kelompok, siswa diminta untuk kembali ke tempat duduk masing-masing. Kemudian peneliti bersama dengan siswa menyimpulkan hasil pembelajaran. Peneliti juga menginformasikan pembelajaran minggu depan masih dengan metode snowball throwing dengan materi pengangguran. Kemudian peneliti membagikan soal post test kepada siswa.

\section{Pengamatan Siklus II}

1) Aktivitas Belajar

Tabel 4. Hasil Perhitungan Persentase Aktivitas Belajar Siklus II

\begin{tabular}{|c|c|c|c|}
\hline Indikater Aktivitas Belajar & Kategori & Persentase & Jumlah SEw/2 \\
\hline \multirow{3}{*}{ Membaca materi pelajaran } & Tidak aktif & $0 \%$ & D \\
\hline & Cukup aktif & $20 \%$ & 4 \\
\hline & Aktif & $\operatorname{sos}$ & 16 \\
\hline \multirow{3}{*}{$\begin{array}{l}\text { Membaat pertanyaan' } \\
\text { menjawzb pertanyaan dari guru } \\
\text { atau teman }\end{array}$} & Tidak aktif & $0 \% 6$ & D \\
\hline & Cukup aktif & $25 \%$ & 5 \\
\hline & Aktif & $75 \%$ & 15 \\
\hline \multirow{3}{*}{$\begin{array}{l}\text { Mendengarkan penjelasan guru } \\
\text { saat pembelajaran }\end{array}$} & Tidak aktif & $a \%$ & D \\
\hline & Cukup aktif & $25 \%$ & 5 \\
\hline & Aktif & $75 \%$ & 15 \\
\hline \multirow{3}{*}{$\begin{array}{l}\text { Mencatat materi pelajaran yang } \\
\text { telah disampaikan guru. }\end{array}$} & Tidak aktif & $\cos$ & D \\
\hline & Cukup aktif & $25 \%$ & 5 \\
\hline & Aktif & $35 \%$ & 15 \\
\hline \multirow{3}{*}{$\begin{array}{l}\text { Bekerja sama dengan teman } \\
\text { sekelompok. }\end{array}$} & Tidak aktif & $6 \%$ & 5 \\
\hline & Cukup aktif & $20 \%$ & 4 \\
\hline & Aktif & soss & 16 \\
\hline \multirow{3}{*}{$\begin{array}{l}\text { Antusias dalam mengikati } \\
\text { pembelajaran dengan } \\
\text { menggunakan metode snowbail } \\
\text { throwing }\end{array}$} & Tidak aktif & $\cos$ & D \\
\hline & Cukup aktif & $10 \%$ & 2 \\
\hline & Aktif & $90 \%$ & 18 \\
\hline Rata - rata indikator aktivitas & Siswa Aktif & $79,17 \%$ & $15,6.3$ \\
\hline
\end{tabular}

Berdasarkan data di atas dapat diketahui dari indikator aktivitas, indikator siswa yang aktif membaca materi pelajaran $80 \%$ atau 16 dari 20 siswa aktif , bertanya kepada guru/peneliti atau teman saat pembelajaran berlangsung 75\% atau 15 dari 20 siswa aktif, mendengarkan penjelasan guru/peneliti $75 \%$ atau 15 dari 20 siswa aktif, mencatat materi pelajaran yang telah dijelaskan oleh guru/peneliti $75 \%$ atau 15 dari 20 mencatat materi yang dijelaskan, berdiskusi dengan sesama anggota kelompoknya 80\% atau 16 dari 20 siswa melaksanakan diskusi di kelas dengan baik dan antusias dalam mengikuti pembelajaran yang berlangsung menggunakan metode snowball throwing $90 \%$ atau 18 
dari 20 siswa antusias dalam melaksanakan pembelajaran dengan metode snowball throwing. Hal ini memberikan kesimpulan bahwa aktivitas belajar siswa di dalam siklus II mengalami peningkatan dibandingkan dengan siklus I dan pembelajaran menggunakan metode snowball throwing ini bisa dikatakan berhasil karena persentase aktivitas belajar lebih dari $75 \%$ dengan rata-rata $79,17 \%$.

2) Hasil Belajar

Tabel 5. Hasil Posttest Siklus II

\begin{tabular}{|c|l|c|}
\hline No & \multicolumn{1}{|c|}{ Keterangan } & Post Test \\
\hline 1 & Nilai Tertinggi & 100 \\
\hline 2 & Nilai Terendah & 70 \\
\hline & Rata - Rata Nilai & 84,7 \\
\hline
\end{tabular}

Tabel 6. Siswa yang sudah dan belum mencapai KKM Siklus II

\begin{tabular}{|c|c|c|c|c|}
\hline \multirow{2}{*}{ Keterangan } & \multicolumn{2}{|c|}{ Jumlah siswa } & \multicolumn{2}{c|}{ Persentase } \\
\cline { 2 - 5 } & $<75$ & $>75$ & $<75$ & $>75$ \\
\hline Post Test & 4 & 16 & $16 \%$ & $84 \%$ \\
\hline
\end{tabular}

Berdasarkan data pada kedua tabel di atas dapat dilihat bahwa rata-rata nilai post test adalah 84,7 pada siklus II. Hal ini menunjukkan bahwa terjadi peningkatan hasil belajar dengan menggunakan metode snowball throwing, pada saat dilaksanakan post test siswa yang mencapai KKM adalah $84 \%$.

Berdasarkan data dari siklus I dan siklus II, aktivitas dan hasil belajar mengalami peningkatan. Pembelajaran menggunakan metode snowball throwing ini bisa dikatakan berhasil karena persentase aktivitas dan hasil belajar lebih dari $75 \%$ dengan persentase aktivitas belajar sebesar 79,19\% sedangkan hasil belajar sebesar $84 \%$, sehingga pembelajaran menggunakan metode snowball throwing ini dapat dikatakan berhasil dan penelitian bisa dihentikan pada siklus II.

\section{Refleksi Siklus II}

Hasil penelitian siklus II menunjukkan adanya peningkatan aktivitas dan hasil belajar siswa. Rencana perbaikan yang dilaksanakan pada siklus I dapat dilaksanakan dengan baik pada siklus II. Hal tersebut terlihat dari data observasi siklus II di mana 6 indikator aktivitas belajar siswa telah mencapai kriteria yang sudah ditetapkan sebesar $75 \%$.

\section{PEMBAHASAN}

Penelitian tindakan kelas ini bertujuan untuk meningkatkan aktivitas dan hasil belajar ekonomi kelas XI IPS SMA Negeri 1 Paguat tahun pelajaran 2019/2020 dengan penerapan metode snowball throwing. Penelitian ini dilatarbelakangi oleh belum maksimalnya aktivitas dan hasil belajar siswa. Penelitian ini dikatakan berhasil 
apabila aktivitas siswa dan mampu menguasai materi yang diajarkan oleh guru dengan hasil belajar siswa yang meningkat.

1. Peningkatan Aktivitas Belajar

Berdasarkan data yang diperoleh mengenai aktivitas belajar selama penelitian ini telah menunjukkan adanya peningkatan aktivitas belajar dari siklus I ke siklus II dengan menggunakan metode snowball throwing. Data sudah dianalisis menggunakan persentase pada setiap indikator aktivitas belajar, kemudian persentase akan dibandingkan antara persentase siklus I dan persentase siklus II untuk mengetahui peningkatannya.

Tabel 8. Kategori Peningkatan Aktivitas Belajar Siswa dari Siklus 1 ke Siklus II

\begin{tabular}{|c|c|c|c|c|c|c|}
\hline $\begin{array}{c}\text { Kategori Keaktifan } \\
\text { Belajar }\end{array}$ & \multicolumn{2}{|c|}{ Siklus I } & \multicolumn{2}{c|}{ Siklus II } & \multicolumn{2}{c|}{$\begin{array}{c}\text { Perubahan } \\
\text { Silklus I ke II }\end{array}$} \\
\cline { 2 - 7 } & F & $\%$ & F & $\%$ & F & $\%$ \\
\hline \multirow{2}{*}{ Tinggi } & $\begin{array}{c}10 \\
\text { siswa }\end{array}$ & $52,63 \%$ & $\begin{array}{c}20 \\
\text { siswa }\end{array}$ & $100 \%$ & $\begin{array}{c}9 \\
\text { siswa }\end{array}$ & $47,37 \%$ \\
\hline Sedang & $\begin{array}{c}8 \\
\text { siswa }\end{array}$ & $42,10 \%$ & $\begin{array}{c}0 \\
\text { siswa }\end{array}$ & $0 \%$ & $\begin{array}{c}-8 \\
\text { siswa }\end{array}$ & $\begin{array}{c}- \\
42,10 \%\end{array}$ \\
\hline Rendah & $\begin{array}{c}1 \\
\text { siswa }\end{array}$ & $5,2 \%$ & $\begin{array}{c}0 \\
\text { siswa }\end{array}$ & $0 \%$ & $\begin{array}{c}-1 \\
\text { siswa }\end{array}$ & $-5,2 \%$ \\
\hline Kurang & $\begin{array}{c}0 \\
\text { siswa }\end{array}$ & $0 \%$ & $\begin{array}{c}0 \\
\text { siswa }\end{array}$ & $0 \%$ & $\begin{array}{c}0 \\
\text { siswa }\end{array}$ & $0 \%$ \\
\hline Jumlah & $\begin{array}{c}19 \\
\text { siswa }\end{array}$ & $100 \%$ & $\begin{array}{c}20 \\
\text { siswa }\end{array}$ & $100 \%$ & $\begin{array}{c}0 \\
\text { siswa }\end{array}$ & $84,27 \%$ \\
\hline
\end{tabular}

Sumber: Data Primer yang diolah

Dari tabel di atas, terlihat bahwa terjadi peningkatkan keaktifan belajar siswa. Pada siklus II seluruh siswa termasuk dalam keaktifan belajar kategori tinggi yaitu sebanyak 20 siswa atau $100 \%$ siswa, dibandingkan dengan siklus I mengalami peningkatan sebanyak 11 siswa atau $52,63 \%$ dari jumlah siswa. Jumlah siswa yang termasuk kategori kategori sedang, kurang maupun rendah pada siklus II .

Dari tabel di atas, dapat disimpulkan bahwa indikator keberhasilan penelitian yaitu $75 \%$ dari jumlah siswa dalam keaktifan belajar kategori tinggi telah terpenuhi. Dari tabel tersebut diketahui bahwa pada siklus I sebesar 52,63\% siswa termasuk dalam keaktifan belajar kategori tinggi, dan pada siklus II meningkat menjadi sebesar $100 \%$. Persentase tersebut juga menunjukkan adanya peningkatkan keaktifan belajar dari siklus I ke siklus II.

Pembelajaran menggunakan metode snowball throwing menunjukkan hasil yang menggembirakan dalam segi aktivitas belajar siswa, hal ini sesuai dengan teori yang dikemukanan oleh Safitri (2011: 19) mengenai kelebihan dari metode snowball throwing. Pembelajaran ini mampu membuat siswa lebih aktif dalam mengemukakan pertanyaan, menjawab pertanyaan, lebih berani bertanya kepada teman, bertanggung jawab terhadap materi kelompoknya dan memahami materi secara mendalam sesuai dengan topik kelompok masing-masing. Persentase rata-rata indikator aktivitas belajar dari siklus I ke siklus II juga mengalami peningkatan, dari $60 \%$ pada siklus I menjadi $79,17 \%$ pada siklus II ini menunjukkan adanya peningkatan aktivitas belajar secara menyeluruh pada semua indikator aktivitas belajar. 


\section{Peningkatan Hasil Belajar}

Peningkatan hasil belajar diukur menggunakan posttest. Berdasarkan hasil tes dapat diketahui adanya peningkatan hasil belajar. Pengukuran hasil belajar bertujuan untuk mengukur sejauh mana siswa telah menguasai materi yang diajarkan. Keberhasilan ini ditunjukkan berdasarkan nilai posttest pada setiap akhir pembelajaran.

Tabel 10. Peningkatan Hasil Belajar Ekonomi

\begin{tabular}{|c|c|c|c|c|c|c|c|}
\hline \multirow[b]{2}{*}{ Siklus } & \multirow[b]{2}{*}{ Ket } & \multirow[b]{2}{*}{$\begin{array}{c}\text { Nilai } \\
\text { Terendah }\end{array}$} & \multirow[b]{2}{*}{$\begin{array}{c}\text { Nilai } \\
\text { Tertinggi }\end{array}$} & \multicolumn{2}{|c|}{ Jml Siswa } & \multicolumn{2}{|c|}{ Pergentase } \\
\hline & & & & $\begin{array}{l}\text { Belum } \\
\text { Tuntas }\end{array}$ & Tuntas & $<75$ & $>75$ \\
\hline I & $\begin{array}{l}\text { Post } \\
\text { Test }\end{array}$ & 60 & 100 & 5 & 14 & $\begin{array}{l}26 \\
\%\end{array}$ & $\begin{array}{l}74 \\
\%\end{array}$ \\
\hline II & $\begin{array}{l}\text { Post } \\
\text { Test }\end{array}$ & 70 & 100 & 4 & 16 & $\begin{array}{l}16 \\
\% \\
\end{array}$ & $\begin{array}{l}84 \\
\% \\
\end{array}$ \\
\hline
\end{tabular}

Sumber: Data Primer yang diolah

Hasil belajar ekonomi siswa pada post test siklus I, siswa yang mencapai KKM adalah 14 anak atau 74\%. Terjadinya peningkatan saat post test siklus II yaitu sebanyak $84 \%$. Hasil belajar ekonomi telah mencapai keberhasilan yaitu dari siklus I sebanyak 11 siswa (74\%) menjadi sebanyak 16 siswa (84\%) pada siklus II. Penelitian ini membuktikan bahwa terjadinya peningkatan hasil belajar siswa dengan menggunakan metode snowball throwing. Dilihat dari hasil belajar yang dicapai siswa, pembelajaran menggunakan metode snowball throwing menunjukkan hasil yang menggembirakan dalam segi hasil belajar siswa, hal ini sesuai dengan teori yang dikemukakan oleh Safitri (2011: 19) mengenai kelebihan dari metode snowball throwing yang mampu membuat siswa lebih aktif dalam mengemukakan pertanyaan, menjawab pertanyaan, lebih berani bertanya kepada teman, bertanggung jawab terhadap materi kelompoknya dan memahami materi secara mendalam sesuai dengan topik kelompok masing-masing. Benang merah dari aktivitas siswa yang semakin meningkat adalah hasil belajar yang ditunjukkan juga semakin meningkat akibat dari penerapan metode snowball throwing. Kelebihan pembelajaran Snowball Throwing sendiri dibandingkan dengan metode pembelajaran yang lain, merupakan paradigma pembelajaran efektif yang merupakan rekomendasi UNESCO, yakni: belajar mengetahui (learning to know), belajar bekerja (learning to do), belajar hidup bersama (learning to live together), dan belajar menjadi diri sendiri (lerning to be). Penggunaan metode pembelajaran Snowball Throwing dapat melibatkan siswa menjadi aktif. Melalui penerapan metode snowball throwing, dapat melatih siswa berani mengemukanan pendapat, bekerja sama dan tanggung jawab, suasana pembelajaran menjadi lebih menyenangkan karena siswa seperti bermain dengan melempar bola kertas kepada kelompok lain.

Hasil dari peningkatan aktivitas belajar dan hasil belajar menunjukkan bahwa tujuan dari penelitian ini telah mencapai indikator keberhasilan. Peningkatan skor aktivitas belajar secara keseluruhan adalah $79,17 \%$, sedangkan hasil belajar ekonomi pada kompetensi dasar sistem upah dan pengangguran mengalami peningkatan ketuntasan sebesar $84 \%$. Oleh karena itu dapat dikatakan bahwa penerapan Metode 
Snowball Throwing dapat meningkatkan Aktivitas Belajar dan Hasil Belajar Ekonomi Siswa Kelas XI IPS SMA Negeri 1 Paguat Tahun Pelajaran 2019/2020.

\section{KESIMPULAN}

Berdasarkan hasil penelitian yang telah dilakukan di SMA Negeri 1 Paguat dapat disimpulkan bahwa:

1. Penerapan metode pembelajaran Snowball Throwing dapat meningkatkan aktivitas belajar siswa kelas XI IPS 1 SMA Negeri 1 Paguat. Aktivitas Belajar siswa yang meliputi tujuh indikator yaitu: membaca materi pelajaran, memperhatikan saat guru menerangkan, bertanya kepada guru atau teman saat pembelajaran berlangsung, mendengarkan penjelasan guru, mencatat materi pelajaran yang telah dijelaskan oleh guru, berdiskusi dengan sesama anggota kelompoknya, antusias dalam mengikuti pembelajaran yang berlangsung. Peningkatan aktivitas belajar secara keseluruhan dibuktikan dengan adanya peningkatan persentase aktivitas belajar sebesar $19,17 \%$, meningkat dari siklus I sebesar $60 \%$ menjadi $79,17 \%$ pada siklus II.

2. Penerapan metode pembelajaran Snowball Throwing dapat meningkatkan hasil belajar siswa kelas XI IPS 1 SMA Negeri 1 Paguat. Hal ini dibuktikan dengan hasil posttest. Hasil belajar ekonomi dari posttest siklus 1 ke posttest siklus II mengalami peningkatan dan sudah menunjukkan tujuan indikator keberhasilan yaitu sebesar 75 $\%$. Siswa yang mampu memenuhi KKM lebih dari $75 \%$ sebanyak 11 siswa atau 74 $\%$ pada siklus 1 menjadi 16 siswa atau $84 \%$ pada siklus II.

\section{SARAN}

Berdasarkan kesimpulan yang telah dikemukakan, maka dalam kesempatan ini peneliti menyarankan sebagai berikut:

1. Lebih mengembangkan penggunaan metode ini dengan penambahan variasi yang berbedaatau menambah variabel, indikator yang berbeda dan mata pelajaran yang berbeda.

\section{DAFTAR PUSTAKA}

Adrian. 2004. http://artikel.us/art05-65.html. Metode Mengajar BerdasarkanTipologi Belajar Siswa. 20-10-2004. 14.00

Asep Jihan dan Abdul haris. (2008). Evaluasi Pembelajaran. Jakarta : Multi Press. Baharuddin. (2007). Teori Belajar dan Pembelajaran. Jogjakarta: Ar-ruzz Media. Dimyanti dan Mudjiono. (2009). Belajar dan Pembelajaran. Jakarta: Rineka Cipta. Djamarah. (2006). Strategi Belajar Mengajar. Jakarta : Rineka Cipta.

Ahmad Susanto, M.Pd. (2013). Teori Belajar dan Pembelajaran. Jakarta: Prenadamedia Group.

Evelin Siregar dan Hartini Nara. (2010). Teori Belajar dan Pembelajaran. Bogor: Ghalia Indonesia.

Furqon Hidayatullah. (2009). Pengembangan Profesional Guru (PPG). Surakarta: Panitia Sertifikasi Guru Rayon 13 Surakarta.

Kokom Komalasari. (2013). Pembelajaran Kontekstual: Konsep dan Aplikasi. Bandung: PT Refika Aditama.

Martinis Yamin. (2007). Kiat Membelajarkan Siswa. Jakarta: Putra Grafika. 
Muhibbin Syah. (2012). Psikologi Belajar. Jakarta: Pt Raja Grafindo Persada.

Nana Sudjana. (2004). Dasar-dasar Proses Belajar Mengajar. Bandung: Sinar Baru Algesindo.

Sardiman. (2012). Interaksi dan Motivasi Belajar Mengajar. Jakarta: Rajawali pers.

Saur Tampubolon. (2013). Penelitian Tindakan Kelas Sebagai Sistem Pengembangan Profesi Pendidik Dan Keilmuan. Jakarta: Erlangga.

Slavin Robert E. (2005). Cooperative Learning: Teori, Riset, dan Praktik (Terjemahan). Bandung: Penerbit Nusa Media.

Sutrisno Hadi. (2004). Metodologi Reseach Jilid 3. Yogyakarta: Andi

Syaiful Bahri Djamarah. (2011). Psikologi Belajar. Jakarta: Renika Cipta.

Tukiran Taniredja, Efi Miftah Faridli, \& Sri Harmianto. (2012). Model-model Pembelajaran Inovatif. Bandung: Alfabeta

Wina Sanjaya. (2013). Strategi Pembelajaran Berorientasi Standar Proses Pendidikan. Jakarta: Kencana. 
AKSARA: Jurnal Ilmu Pendidikan Nonformal

P-ISSN 2407-8018 E-ISSN 2721-7310 DOI prefix 10.37905

Volume 08, (1), January 2022

http://ejurnal.pps.ung.ac.id/index.php/Aksara

362 AKSARA: Jurnal Ilmu Pendidikan Nonformal 